\title{
THE IMPACT OF TEACHER'S TEACHING EXPERIENCE ON THE IMPLEMENTATION OF ENGLISH LANGUAGE CURRICULA IN PUBLIC SCHOOLS IN AQABA GOVERNORATE, JORDAN
}

\author{
Eman Saleh Al- Sagier Shaiegy ${ }^{1}$ \\ ${ }^{1}$ Ministry of Education, Jordan \\ ARTICLE INFO \\ Received: 09 October 2021 \\ Revised: 14 November 2021 \\ Accepted: 14 November 2021 \\ Keywords: \\ Curriculum Implementation, \\ Teaching Experience, \\ Needs \\ Corresponding Author: \\ Eman Shaiegy \\ Email: emanshaiegy@yahoo.com \\ Copyright () 2021, Middle Eastern \\ Journal of Research in Education \\ and Social Sciences. \\ This work is licensed under the \\ Creative Commons Attribution \\ International License (CC BY 4.0). \\ http://creativecommons.org/licenses/ \\ by/4.0/
}
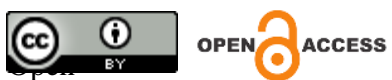

\begin{abstract}
Purpose: This study investigated the impact of teachers' teaching experience on the implementation of English language curricula in public schools in the Aqaba Governorate, Jordan.

Approach/Methodology/Design: The Rand Change Agent Theory of curriculum implementation guided this study. A descriptive survey design was adopted. The sample included 167 English language teachers who were selected purposively from 240 public school teachers in the Aqaba Governorate, Jordan. A questionnaire was developed as an instrument for data collection. It consisted of 36 items, and it was validated by presenting it to a group of arbitrators. The reliability was assured by carrying out a test-retest on a sample chosen from outside the sample of the study. Descriptive statistics were utilized to analyze data.
\end{abstract}

Findings: The study findings indicated that there are statistically significant differences at $(\alpha \leq 0.05)$ between the implementation of English language curricula and the teacher's teaching experience. This means that the teaching experience of the teacher affects the implementation of English language curricula.

Practical Implications: The study presents certain implications for curriculum development policies. The study recommends engaging teachers in programs that assist them in exchanging experiences, knowledge, and skills to ensure effective execution of the curriculum in addition to the necessity for teachers to pay attention to self-development.

Originality/value: Teaching experience plays a crucial role in curriculum implementation. It enables teachers to gain competence and effectiveness.

\section{INTRODUCTION}

There are many variables related to the teacher that impact his/ her effectiveness and ability to carry out the curriculum like gender, age, motivation, competence, teaching techniques, intelligence, satisfaction, belief, attitude, professional and academic qualification (Sawhney \&Kour, 2011; Ummekusum \& Khajapeer, 1985; Wingington, Tollefson \& Rodriguez, 1989). Teaching experience is one of the important factors that impact the performance of the teacher and this is asserted by many researchers such as Akinleye (2001), Commeyras (2003), Musfah (2011), Mutoro (2001), Nengwekhulu's (2008), Ogundare (2001), and Santoso (2012). 
Teaching experience is considered a repository of knowledge and skills that the teacher obtained and developed during the years of teaching and it is also considered as an indicator of what the teacher is familiar with and accustomed to from the various teaching practices that help him or her to carry out the curriculum effectively (Wandra, 2019). A teacher with more teaching experience is best able to implement the curriculum professionally due to the knowledge and skills that he/ she has obtained during the long years of instruction in addition to the training courses, conferences, seminars and workshops that they attended which assisted them to prevent the occurrence of problems that hinder the process of carrying out the curriculum (Wolters \& Daugherty, 2007).

A teacher's teaching experience impacts the development of students' performance (Huang \& Moon, 2009; Ongele, 2007; Papay \& Kraft, 2007; Rice, 2010; Strauss \& Vogt, 2001; Thuranira, 2010). Many studies have indicated the role of teacher's teaching experience in improving students' achievement in learning English (Hariss \& Sass, 2008; Komolafe, 1989; Ojo 2008; Robinson, 2009; Rock off, 2004; Wandera, 2019). According to Musfah (2011), sufficient or long experience of the teacher positively impacts his/her teaching practices in the classroom and improves his/ her ability to carry out the curricula in a better way. From the researcher's point of view and through her personal experience in instruction and administration, she noticed that the teacher with the most experience is usually the one who can carry out the curriculum effectively and efficiently because little or insufficient experience affects his/ her understanding of the curriculum. Therefore, he/she usually needs many years to possess the knowledge and skills that enable him/ her to carry out the curriculum successfully. The teaching experience plays an important role in the execution of the curriculum which in turn is reflected in the performance of the students. Therefore, this study aimed to investigate the impact of teaching experience as one of the teacher-related factors that impact the implementation of English language curricula in public schools in the Aqaba Governorate, Jordan.

The present study is important because it draws the attention of decision-makers to the importance of pre-service and in-service training to develop teachers' skills and competencies which help them overcome the challenges they face in the process of implementing the curriculum. It also enriches the literature with further studies on the implementation of the curriculum and opens the way for more studies. Finally, it helps curriculum designers and teachers to develop the process of executing the curriculum using the findings of the current study.

\section{LITERATURE REVIEW}

There are many empirical studies related to the impact of teachers' teaching experience on curriculum implementation. Kinyua (2012) examined the influence of teaching experience as one of the factors related to the teacher that affect the execution of integrated Kiswahili curriculum in public secondary schools. The study sample consisted of 68 participants and they were selected by using the purposive technique. To collect data, an interview schedule and questionnaires were used. The descriptive survey design was adopted in this study. The results of the study indicated that teachers' teaching experience impacted the implementation of the integrated Kiswahili curriculum. The researcher recommended that the Ministry of Education 
should organize training courses for teachers that help them in carrying out the integrated Kiswahili curriculum.

Owusu and Yiboe (2013) explored teaching experience as a predictor of implementation of the senior high school (SHS) French curriculum in Ghana. The study sample consisted of 21 French teachers and they were selected purposively. A simple descriptive design was utilized. A questionnaire was used to collect data. The findings showed the impact of teaching experience only occurred by chance and not because of any statistical significance. The researcher recommended the Ministry of Education should qualify teachers who are already in the teaching service but do not have the necessary qualifications to improve their ability to carry out curriculum effectively.

Linet (2014) investigated the impact of teaching experience on the execution of the Integrated English Curriculum in public secondary schools in the Ekerengo Division. The study adopted a descriptive survey design. The study sample consisted of 49 participants and they were selected by using purposive sampling. To collect data, an interview schedule and questionnaire were utilized and data were analyzed by using descriptive statistics. The findings of the study revealed that teachers' teaching experience impacted the effective implementation of the Integrated English Curriculum. The researcher recommended that more training programs should be organized by the Ministry of Education, in addition to the necessity of involving teachers in the development of the new curriculum to ensure it is suitable for the level of students. The Ministry of Education should also guarantee that English is taught by qualified and experienced teachers to ensure the effective execution of the curriculum.

Kigwilu and Githinji (2015) investigated the effect of teaching experience among other factors on the effective execution of Artisan and Craft courses in community colleges in Nairobi, Kenya. Mixed methods research design was adopted in this study. The study sample consisted of twenty-four Artisan and Craft teachers and four directors of community colleges. The interviews guides and questionnaires were utilized to collect data. Descriptive statistics were utilized to analyze quantitative data while qualitative data were analyzed and presented in form of narratives and direct quotations. The study findings revealed that teaching experience had a significant impact on the execution of the Artisan and Craft curriculum so the researcher recommended appointing qualified and experienced teachers and also helping the teachers to build and develop their capabilities and skills that guarantee effective implementation of the Artisan and Craft curriculum.

Vicky (2016) examined the influence of teaching experience in addition to other factors related to the teacher that impact the execution of the Integrated English Curriculum (IEC) in Mandi East sub-county, Kenya. The study employed a descriptive survey design. The study sample consisted of 12 headteachers, 12HoDs, 24 teachers of English, and 300 students. To data collect data, questionnaires and interview guides were utilized and data were analyzed using descriptive statistics. The study findings revealed that teaching experience strongly affected the implementation of IEC. The more experienced teachers were confident and got better results because they learned over time how to carry out the curriculum correctly and deal with students at all levels. In addition to that, the students preferred experienced (older) teachers to teach them because they were familiar with the content of the curriculum they teach than younger teachers 
who had less experience. The researcher recommended that pre-service teacher training should be specifically designed to guarantee the teaching of English language and literature as integrated courses by teacher education colleges. In addition to that encouraging conferences between schools to demystify the curriculum and its implementation.

Tenai (2017) investigated the teaching experience among other variables that impact the integration of ICTs in teaching the English language in secondary schools in Eldoret East Sub County, Kenya. The Diffusion of Innovation Theory and The Rand Change Agent Theory guided this study. A descriptive survey design was employed. The sample size comprised of 51 teachers of English language who were chosen purposively from 17 public secondary schools which were selected randomly. A questionnaire was utilized to collect data which was analyzed using both descriptive and inferential statistics. The findings of the study showed that there was a significant correlation between teaching experience and technology literacy. The researcher recommended that teachers (male and female) need to be urged to improve ICT literacy through training to empower them to integrate ICT for teaching and promoting students' performance of specified objectives.

Rahaman (2018) investigated teacher-related variables such as teaching experience among other variables that impact the implementation of the Communicative Language Teaching (CLT) curriculum in secondary schools in Bangladesh. The study sample consisted of eight teachers. A purposive sampling technique was utilized. The study used mixed methods research design. To collect data, semi-structured interviews, classroom observation, document analysis of curriculum, assessment, and teaching materials were employed. The findings revealed that several factors were affecting the curriculum to be executed through the teachers' practice of CLT in the classroom. The researcher recommended that the Ministry of Education should qualify teachers to empower them to carry out the Communicative Language Teaching (CLT) curriculum effectively.

\section{Effects of Teaching Experience on Curriculum Implementation}

The Rand Change Agent Theory of curriculum implementation guided this study (Berman \& Mclaughlin, 1978). This theory suggests that teachers who have instructed for many years may find it easy to carry out the curricula efficiently. According to Seweje and Jegede (2005), a teacher's ability to teach is not only derived from the academic background of the individual but it is based upon the outstanding skills acquired. Adeyemi (2008), examined teachers' teaching experience and students' learning outcomes in secondary schools in Ondo State Nigeria and asserted that schools that included more teachers with 5 years and above teaching experience achieved better results than the schools that included more teachers with less than 5 years teaching experience. Harris and Sass (2011) indicated that all the studies of teacher productivity include some measures of teacher's experience. They found that there was an incredible contrast between the approach followed by a starting teacher and that of an experienced teacher. The more experience a teacher has acquired over some time, the more capable and proficient he is in his work.

Mogoma (2011) noticed in his study on curriculum execution in Kenya that teacher's teaching experience in teaching is very significant in relation to the carrying out of any curriculum. 
Experience empowers the teacher to acquire confidence and competence. Similarly, Olivia (1988) also asserted that a teacher gains skills through experience and the more experience a teacher has, the more successful he is in his work. Mutoro (2011) asserted this and stated that the teaching experience of the teacher identifies the efficiency and effectiveness in implementing curricula. Therefore, the teacher's experience has great importance in the implementation of the curriculum. Barners (1985), however, observed that the correlation between teaching experience and teaching effectiveness is curvilinear and there is a general negative connection between the years that the teacher has been educated and the effectiveness of the teacher. The issue about the connection between years of experience and execution has not been a recent phenomenon, investigations of teacher experience have been directed in a wide scope of developed and developing countries (Hanushek, 2003). Several studies carried out in the past indicated that the teacher's teaching experience has a more positive connection with the quality of teaching or execution, but the general picture is still not strong (Hanushek, 2003). While most studies found a positive effect, only a minority provided a statistically significant result. Hanushek additionally pursued a nonparametric investigation of experience and revealed that the influences of experiences are concentrated in the initial few years of instruction. Similarly, many studies also supported this such as the studies of Dunkin (1997), Rice ( 2004), Rockoff (2004), Bauer (2005), Hanushek, Kain, O’Brien \& Rivkin (2005), Boyd, Grossman, Lankford, Loeb, \& Wyckoff, (2008 a), Boyd, et al., (2008 b), Clotfelter, Ladd \& Vigdor (2007a ), Clotfelter et al, ( 2007 b), Fantilli \& McDougall (2009), and Jacob, 2012).

The findings of previous studies showed the influence of teachers' teaching experience on the execution of the curricula. Previous studies helped the researcher in building the theoretical framework for the current study, its question, hypothesis and instrument in addition to selecting the sample, references, statistical analysis and discussing the results. The present study is distinguished from the previous studies in that it was conducted in Jordan whose environment is completely different from the environments in which the previous studies were conducted. Also the possibility of benefiting from the current study instrument in building and developing other instruments to measure the same variable or other variables related to the teacher that impacts the implementation of the curricula.

\section{METHODOLOGY AND PROCEDURES}

\section{Design of the Study}

A descriptive survey design was used to achieve the aim of this study. Descriptive research involves naturalistic data. Language learning and teaching are studied in their naturally occurring settings without any intervention or manipulation of variables (Nassaji, 2015).

\section{Population and Sampling of the Study}

The study population consisted of 240 English language teachers (66 males and 174 females) according to the statistics of the Education Directorate of Aqaba. 167 English language teachers were chosen purposively to participate in this study (119 females and 48 males).

\section{Instrument of the Study}


A questionnaire was used in the current study and is comprised of two parts: the first included demographic data such as gender, age, years of experience, training courses, qualification, and the second included six domains (content, objectives, educational activities, educational aids, teaching methods, and evaluation) and each domain included six items so the questionnaire items were 36. The study sample was asked to select the appropriate answer from the Likert five-point scale.

\section{Validity of the Instrument}

The suggestions and opinions of twenty-one arbitrators from Jordanian university professors, supervisors, and teachers in the Aqaba Education Directorate were taken into consideration to ensure the validity of the questionnaire. To extract the significance of the construct validity of the questionnaire, correlation coefficients of each item and the total score, between each item and its correlation in the domain to which it belongs and between the domains and the total score were calculated. The correlation coefficients of the items with the tool ranged between (0.67- 0.97) and with the domain (0.70-0.97) and the table (1) below shows that.

Table 1: Correlation Coefficients between the Item and the Total Score and the Domain to which it belongs

\begin{tabular}{|c|c|c|c|c|c|c|c|c|}
\hline $\begin{array}{l}\text { Item } \\
\#\end{array}$ & $\begin{array}{l}\mathrm{R} \\
\text { With } \\
\text { Domain }\end{array}$ & $\begin{array}{l}\text { R } \\
\text { With } \\
\text { total } \\
\text { score }\end{array}$ & $\begin{array}{l}\text { Item } \\
\#\end{array}$ & $\begin{array}{l}\mathrm{R} \\
\text { With } \\
\text { Domain }\end{array}$ & $\begin{array}{l}\mathrm{R} \\
\text { With } \\
\text { total } \\
\text { score }\end{array}$ & $\begin{array}{l}\text { Item } \\
\#\end{array}$ & $\begin{array}{l}\mathrm{R} \\
\text { With } \\
\text { Domain }\end{array}$ & $\begin{array}{l}\mathrm{R} \\
\text { With } \\
\text { total } \\
\text { score }\end{array}$ \\
\hline 1 & $.70 * *$ & $.67 * *$ & 13 & $.78 * *$ & $.84 * *$ & 25 & $.83 * *$ & $.81 * *$ \\
\hline 2 & $.75^{* *}$ & $.71 * *$ & 14 & $.90 * *$ & $.87 * *$ & 26 & $.81 * *$ & $.69 * *$ \\
\hline 3 & $.79 * *$ & $.80 * *$ & 15 & $.92 * *$ & $.90 * *$ & 27 & $.83 * *$ & $.76^{* *}$ \\
\hline 4 & $.92 * *$ & $.90 * *$ & 16 & $.94 * *$ & $.93 * *$ & 28 & $.76^{* *}$ & $.68 * *$ \\
\hline 5 & $.90 * *$ & $.92 * *$ & 17 & $.85^{* *}$ & $.80 * *$ & 29 & $.85^{* *}$ & $.90 * *$ \\
\hline 6 & $.75^{* *}$ & $.71 * *$ & 18 & $.87 * *$ & $.78 * *$ & 30 & $.88 * *$ & $.94 * *$ \\
\hline 7 & $.93 * *$ & $.97 * *$ & 19 & $.90 * *$ & $.91 * *$ & 31 & $.91 * *$ & $.90 * *$ \\
\hline 8 & $.91 * *$ & $.89 * *$ & 20 & $.94 * *$ & $.94 * *$ & 32 & $.89 * *$ & $.84 * *$ \\
\hline 9 & $.91 * *$ & $.83 * *$ & 21 & $.92 * *$ & $.90 * *$ & 33 & $.94 * *$ & $.82 * *$ \\
\hline 10 & $.95 * *$ & $.92 * *$ & 22 & $.91 * *$ & $.90 * *$ & 34 & $.93 * *$ & $.84 * *$ \\
\hline 11 & $.84 * *$ & $.77 * *$ & 23 & $.97 * *$ & $.96^{* *}$ & 35 & $.94 * *$ & $.79 * *$ \\
\hline 12 & $.87 * *$ & $.82 * *$ & 24 & $.90 * *$ & $.86 * *$ & 36 & $.85^{* *}$ & $.74 * *$ \\
\hline
\end{tabular}

The previous table indicates that all correlation coefficients were acceptable and statistically significant degree so none of these items were deleted.

\section{Reliability of the Instrument}

Test-retest was employed to verify the questionnaire reliability. The researcher applied the questionnaire to a sample of twenty English language teachers from the study population over a period of two weeks and then excluded them from the study sample. Then the Pearson Correlation Coefficient was extracted between their estimates both times. The values in the Table 2 below were considered suitable to ensure the questionnaire reliability.

Table 2: Test - Retest of the Study Domains

Domains Test-retest




\begin{tabular}{cc}
\hline Content & $.881(* *)$ \\
Outcomes & $.946(* *)$ \\
Educational activities & $.887(* *)$ \\
Educational aids & $.824(* *)$ \\
Teaching methods & $.936(* *)$ \\
Evaluation & $.784(* *)$ \\
$* *$ Correlation is significant at the 0.01 level (2-tailed). & $.901(* *)$ \\
\hline Curriculum implementation scale
\end{tabular}

In addition, Cronbach alpha was calculated to ensure the reliability of the questionnaire. The values ranged between (0.81-0.95) and this is an acceptable result as shown underneath in table (3).

Table 3: The Reliability Level for Study Domains

\begin{tabular}{lcc}
\hline $\mathrm{N}$ & Domains & Cronbach alpha \\
\hline 1 & Content & 0.82 \\
2 & Outcomes & 0.83 \\
3 & Educational activities & 0.83 \\
4 & Educational aids & 0.81 \\
5 & Teaching methods & 0.82 \\
6 & Evaluation & 0.82 \\
& Curriculum implementation scale & 0.95 \\
\hline
\end{tabular}

\section{Data Collection}

The researcher distributed the questionnaires electronically to the study sample in the second semester of the academic year (2020-2021) and sent reminders to increase the participation rate.

\section{RESULTS AND DISCUSSION}

To answer the study question, means and standard deviations of the implementation of English curricula according to teachers' experience variables were computed as presented in table Table 4.

Table 4: Means and Standard Deviations of the Implementation of English Curricula According to Teaching Experience Variable.

\begin{tabular}{lllll}
\hline Domains & Years of experience & $\mathrm{N}$ & Mean & Std. Deviation \\
\hline Content & 10 years or less & 50 & 4.10 & .423 \\
& $11-20$ & 93 & 4.09 & .491 \\
& more than 20 years & 24 & 4.44 & .395 \\
Total & 167 & 4.14 & .473 \\
& 10 years or less & 50 & 4.06 & .512 \\
& $11-20$ & 93 & 4.10 & .487 \\
Educational activities & more than 20 years & 24 & 4.46 & .472 \\
& Total & 167 & 4.14 & .508 \\
& 10 years or less & 50 & 4.00 & .496 \\
& $11-20$ & 93 & 3.97 & .478 \\
& more than 20 years & 24 & 4.38 & .488 \\
\hline
\end{tabular}




\begin{tabular}{lllll}
\hline Domains & Years of experience & $\mathrm{N}$ & Mean & Std. Deviation \\
Educational aids & Total & 167 & 4.04 & .502 \\
& 10 years or less & 50 & 4.05 & .443 \\
& $11-20$ & 93 & 4.05 & .480 \\
Teaching methods & more than 20 years & 24 & 4.35 & .499 \\
& Total & 167 & 4.09 & .481 \\
& 10 years or less & 50 & 4.04 & .402 \\
Evaluation & $11-20$ & 93 & 3.96 & .509 \\
& more than 20 years & 24 & 4.27 & .510 \\
& Total & 167 & 4.02 & .489 \\
Curriculum & 10 years or less & 50 & 4.29 & .479 \\
scale & $11-20$ & 93 & 4.27 & .443 \\
& more than 20 years & 24 & 4.58 & .374 \\
& Total & 167 & 4.32 & .455 \\
& 10 years or less & 50 & 4.09 & .378 \\
& $11-20$ & 93 & 4.07 & .408 \\
& more than 20 years & 24 & 4.41 & .395 \\
& Total & 167 & 4.13 & .412 \\
\hline
\end{tabular}

Table 4 shows a slight variance in means of the implementation of English curricula according to teaching experience variable, to find out whether there are statistically significant differences in these means, One way ANOVA was conducted, and the results are shown in table (5).

Table 5: One Way ANOVA Results of the Implementation of English Curricula according to Teaching Experience Variable

\begin{tabular}{|c|c|c|c|c|c|c|}
\hline \multirow[t]{2}{*}{ Domains } & & \multicolumn{2}{|c|}{ Sum of } & \multicolumn{3}{|l|}{ Mean } \\
\hline & & Squares & Df & Square & $\mathrm{F}$ & Sig. \\
\hline \multirow[t]{3}{*}{ Content } & Between Groups & 2.553 & 2 & 1.277 & 6.066 & .003 \\
\hline & Within Groups & 34.518 & 164 & .210 & & \\
\hline & Total & 37.071 & 166 & & & \\
\hline \multirow[t]{3}{*}{ Outcomes } & Between Groups & 2.938 & 2 & 1.469 & 6.047 & .003 \\
\hline & Within Groups & 39.839 & 164 & .243 & & \\
\hline & Total & 42.777 & 166 & & & \\
\hline \multirow[t]{3}{*}{ Educational activities } & Between Groups & 3.280 & 2 & 1.640 & 6.982 & .001 \\
\hline & Within Groups & 38.524 & 164 & .235 & & \\
\hline & Total & 41.804 & 166 & & & \\
\hline \multirow[t]{3}{*}{ Educational aids } & Between Groups & 1.829 & 2 & .914 & 4.104 & .018 \\
\hline & Within Groups & 36.541 & 164 & .223 & & \\
\hline & Total & 38.370 & 166 & & & \\
\hline \multirow[t]{3}{*}{ Teaching methods } & Between Groups & 1.910 & 2 & .955 & 4.151 & .017 \\
\hline & Within Groups & 37.736 & 164 & .230 & & \\
\hline & Total & 39.646 & 166 & & & \\
\hline \multirow[t]{3}{*}{ Evaluation } & Between Groups & 1.910 & 2 & .955 & 4.817 & .009 \\
\hline & Within Groups & 32.514 & 164 & .198 & & \\
\hline & Total & 34.424 & 166 & & & \\
\hline Curriculum & Between Groups & 2.323 & 2 & 1.162 & 7.359 & .001 \\
\hline \multirow[t]{2}{*}{ implementation scale } & Within Groups & 25.885 & 164 & .158 & & \\
\hline & Total & 28.208 & 166 & & & \\
\hline
\end{tabular}


Table 5 shows that there are statistically significant differences at $(\alpha \leq 0.05)$ between the means of the implementation of English curricula according to teachers' experience variable. Pairwise Multiple Comparisons Post Hoc Test using Scheffe method was conducted as shown in table 6 :

Table 6: Pairwise Multiple Comparisons Post Hoc Tests Using Scheffe Method on the Implementation of English Curricula According to Teaching Experience Variable

\begin{tabular}{|c|c|c|c|c|c|}
\hline $\begin{array}{l}\text { Dependent } \\
\text { Variable }\end{array}$ & (I) Teaching experience & (J) Teaching experience & $\begin{array}{l}\text { Mean Difference } \\
(\mathrm{I}-\mathrm{J})\end{array}$ & Std. Error & Sig. \\
\hline \multirow[t]{6}{*}{ Content } & 10 years or less & $11-20$ & .01 & .080 & .996 \\
\hline & & more than 20 years & $-.35^{*}$ & .114 & .011 \\
\hline & $11-20$ & 10 years or less & -.01 & .080 & .996 \\
\hline & & more than 20 years & $-.35^{*}$ & .105 & .004 \\
\hline & more than 20 years & 10 years or less & $.35^{*}$ & .114 & .011 \\
\hline & & $11-20$ & $.35^{*}$ & .105 & .004 \\
\hline \multirow[t]{6}{*}{ Outcomes } & 10 years or less & $11-20$ & -.04 & .086 & .889 \\
\hline & & more than 20 years & $-.40 *$ & .122 & .005 \\
\hline & $11-20$ & 10 years or less & .04 & .086 & .889 \\
\hline & & more than 20 years & $-.36^{*}$ & .113 & .007 \\
\hline & more than 20 years & 10 years or less & $.40^{*}$ & .122 & .005 \\
\hline & & $11-20$ & $.36^{*}$ & .113 & .007 \\
\hline \multirow{6}{*}{$\begin{array}{l}\text { Educational } \\
\text { activities }\end{array}$} & 10 years or less & $11-20$ & .03 & .085 & .957 \\
\hline & & more than 20 years & $-.38^{*}$ & .120 & .008 \\
\hline & $11-20$ & 10 years or less & -.03 & .085 & .957 \\
\hline & & more than 20 years & $-.41 *$ & .111 & .002 \\
\hline & more than 20 years & 10 years or less & $.38^{*}$ & .120 & .008 \\
\hline & & $11-20$ & $.41^{*}$ & .111 & .002 \\
\hline \multirow{5}{*}{$\begin{array}{l}\text { Educational } \\
\text { aids }\end{array}$} & 10 years or less & $11-20$ & .00 & .083 & .999 \\
\hline & & more than 20 years & $-.30 *$ & .117 & .040 \\
\hline & $11-20$ & 10 years or less & .00 & .083 & .999 \\
\hline & & more than 20 years & $-.30 *$ & .108 & .025 \\
\hline & more than 20 years & 10 years or less & $.30 *$ & .117 & .040 \\
\hline
\end{tabular}




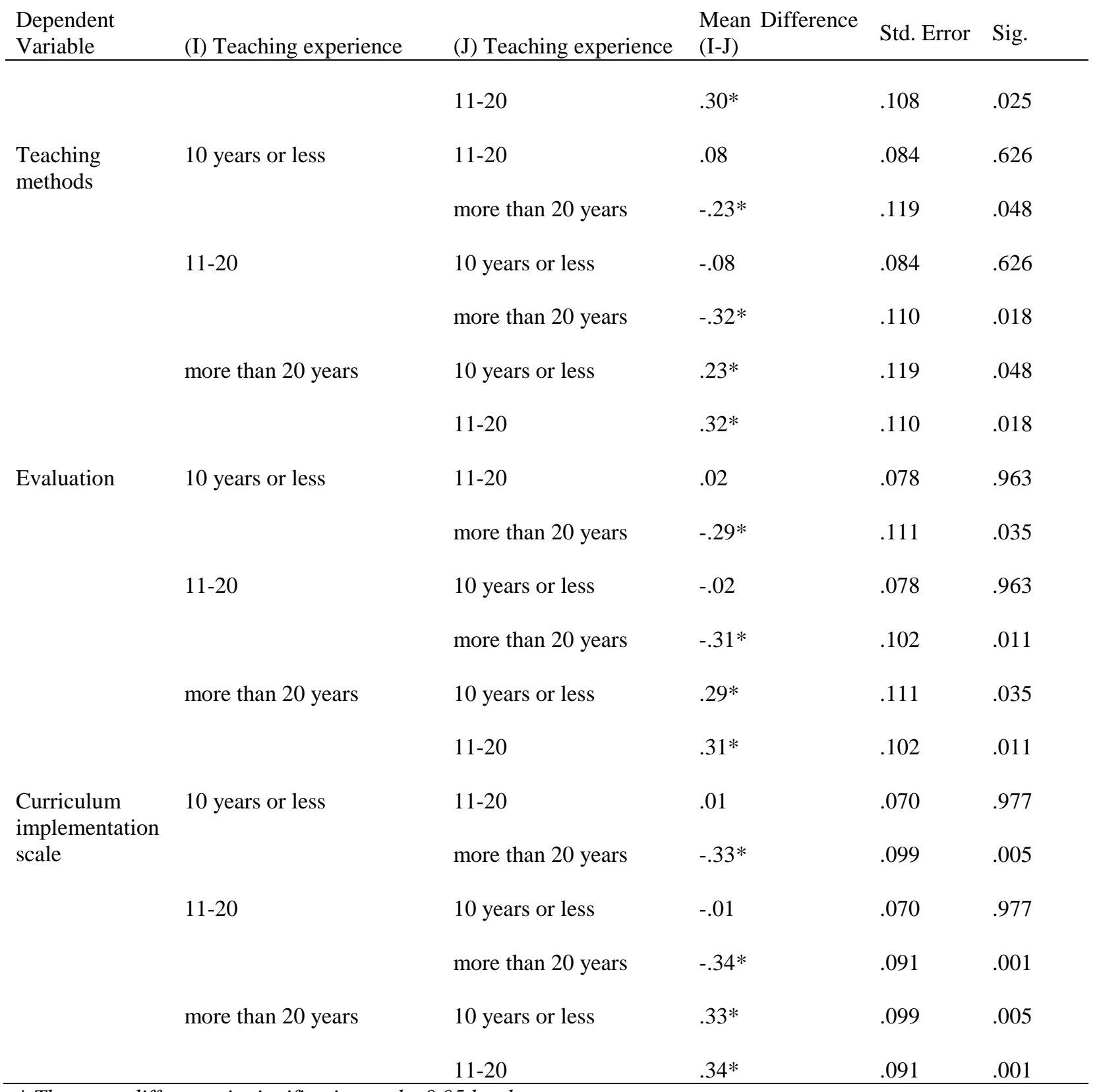

\footnotetext{
* The mean difference is signification at the 0.05 levels.
}

The above table 6 shows that there is a statistically significant difference at $(\alpha \leq 0.05)$ between more than 20 years from one side and between each of 10 years or less and 11-20 years from the other side in favor to those whose levels of experiences more than 20 years where the mean was higher in all variables. This implies that the teachers who had taught English for more than twenty years have gained a lot of experience in executing English language curricula. This, therefore, means that teachers' teaching experiences have an impact on curriculum implementation.

\section{Discussion}

The findings revealed that there were significant differences between the implementation of English language curricula and teachers' teaching experience. This means that the teaching 
experience as a variable can be described as an effective factor in determining the degree of execution of English language curricula.

The results of the current study showed that the differences were in favor of teachers who had an experience of more than 20 years compared with teachers who had an experience of 10 years or less and 11-20 years. Based on this result, it can be said that teaching experience plays a crucial role in curriculum implementation. It enables teachers to gain competence and effectiveness and this was confirmed by Barner (1985), Olivia (1988), Mutoro (2001) and Mogoma (2011).This is also confirmed by the Rand Change Agent Theory (the theory that guided this study) and this theory supposed that teachers who have taught for many years may find it easier to bypass modern teaching strategies and teaching materials quickly and effectively.

This result can be explained in the light that the more years of teaching experience teachers have, the more they possess the skills and knowledge that enable them to effectively implement the curricula. In addition, the more years of teaching experience for teachers, the more familiar they become with the educational programs that help them improve their teaching practices. The result can be also attributed to the fact that the Ministry of Education provides training programs and courses for teachers that will raise their educational, scientific and professional competence, as training in these programs and courses is according to seniority, experience, and academic rank which leaves a real impact for the experience factor.

The result of this question is in agreement with the result of Vicky (2014) and Kigwiln and Githinji (2015) who stated that teaching experience strongly affects curriculum implementation. The study of Owusu and Yiboe (2013) agreed with the result of this study but the effect of teaching experience on curriculum implementation only happened by chance, not due to any statistical significance. Moreover, the result of Kibet (2017) study also matches the result of the current study. The result of the current study differed from the studies of Dunkin ( 1997), Hanushek (2003), Rice ( 2004), Rockoff (2004), Bauer (2005), Hanushek, Kain, O'Brien \& Rivkin (2005), Boyd, Grossman, Lankford, Loeb, \& Wyckoff, (2008 a), Boyd, et al., (2008 b), Clotfelter, Ladd \& Vigdor (2007a ) and Clotfelter et al, ( 2007 b), Fantilli \& McDougall (2009), and Jacob, 2012) who found that the experience effects are concentrated in the first few years of teaching.

\section{CONCLUSION AND SUGGESTION}

Teaching experience as one of the factors related to the teacher is significant and impacts the process of implementing the curriculum. The study findings agree with the Rand Change Agent Theory of curriculum implementation which was adopted by this study, which confirms that teachers with more experience are able to carry out the curriculum easily and successfully. Based on the findings, the researcher recommends that the Ministry of Education should diversify programs for exchanging scientific and specialized experiences and programs for seminars, conferences to develop teachers' competence and their ability to carry out curricula. In addition to that school, administrations should carry out exchange visit programs for teachers with other schools so that teachers could benefit from each other's experiences in carrying out 
curricula. Also, teachers themselves should constantly seek to update their knowledge and skills throughout their teaching career to increase their ability to execute English language curricula.

\section{CONFLICT OF INTEREST}

There are no conflicts of interest with this paper.

\section{FUNDING}

No funding was received to complete this research.

\section{REFERENCES}

Adeyemi, T.O. (2008). Teachers Teaching Experience and Students Learning Outcomes in Secondary Schools in Ondo State Nigeria, Educational Research and Review, 3 (6), 204-212. https://doi.org/10.4314/ajesms.v3i1.38607

Akinleye, G. A. (2001). Early Childhood Education: Guide for Parents and Teachers. UAD Journal of Education, 2 (1) October; 45.

Barnes, J.(1985). An International Encyclopedia of Educational Research studies, New York: Pergamon Press.

Berman, P, \& McLaughlin, M. W.(1978). Federal Programs Supporting Educational Change, Vol. VIII: Implementing and Sustaining Innovations. Santa Monica, CA: Rand.

Boyd, D., Grossman, P., Lankford, H., Loeb, S., \& Wyckoff, J. (2008a). Teacher Preparation and Student Achievement (NBER Working Paper No. 14314). Available online at http://www.nber.org/papers/w14314.pdf

Boyd, D., Grossman, P., Lankford, H., Loeb, S., \& Wyckoff, J. (2008b, May). Who Leaves? Teacher Attrition and Student Achievement (NBER Working Paper No. 14022). Available online at http://www.nber.org/papers/w14022.pdf

Boyd., D., Lankford, H., Loeb, S., \& Wyckoff, J. (2010). Teacher Layoffs: An Empirical Illustration of Seniority Versus Measures of Effectiveness. Education Finance and Policy, 6 (3), 439-454. https://doi.org/10.1162/EDFP_a_00041

Clotfelter, C., Ladd, H., \& Vigdor, J. (2007a). How and Why Teacher Credentials Matter for Student Achievement? (NBER Working Paper No. 12828). http://www.nber.org/papers/w12828.pdf

Clotfelter, C., Ladd, H., \& Vigdor, J. (2007b). Teacher Credentials and Student Achievement in High School: A cross-subject Analysis with Student Fixed Effects (NBER Working Paper No. 13617). http://www.nber.org/papers/w13617.pdf

Commeyras, M. (2003). Promoting a Culture of Reading. The Comet Thursday, February 13; 31- 32.

Directions Evidence and Policy Research Group, LLP. (2014). Ontario Regulation 274-Fina Report. Available online at http://www.edu.gov.on.ca/eng/policyfunding/memos/nov2014/REG274EN.pdf

Dunkin, M. J. (1997). Assessing Teachers' Effectiveness. Issues in Educational Research, 7(1), 37- 51. Available online at http://education.curtin.edu.au/iier/iier7/dunkin.html

Fantilli, R., \& McDougall, D. (2009). A Study of Novice Teachers: Challenges and Supports in the First $\begin{array}{llll}\text { Years. } \quad \text { Teaching } & \text { 25 }\end{array}$ https://doi.org/10.1016/j.tate.2009.02.021

Hanushek, E. (2003). The Failure of Input-Based Schooling Policies. Economic Journal, 113 (2), 64-98. https://doi.org/10.1111/1468-0297.00099

Hanushek, E., Kain, J., O’Brien, D., \& Rivkin, S. (2005). The Market for Teacher Quality. NBER Working Paper 11154. Cambridge, MA: National Bureau of Economic Research. Available online at http://www.nber.org/papers/w11154.pdf

Harris, D.N and Sass, T.R. (2008). Teacher Training Teacher Quality and Student Achievement. 
National Enter for Analysis of longitudinal Data for Educational Research. U.S.A. https://doi.org/10.3386/w21922

Harris, D.,\& Sass, T. (2011). Teacher Training, Teacher Quality and Student Achievement. Journal of Public Economic, 95(7-8), 798-812. https://doi.org/10.1016/j.jpubeco.2010.11.009

Huang, F., \& Moon, T. (2009). Is Experience the Best Teacher? A multilevel Analysis of

Teacher Characteristics and Student Achievement in Low Performing Schools. Educational Assessment Evaluation and Accountability, 21(3), 209-234. htps://doi.org/10.1007/s11092$\underline{009-9074-2}$

Jacob, A. (2012). Examining the Relationship between Student Achievement and Observable Teacher Characteristics: Implications for School Leaders. International Journal of Educational Leadership Practices, 7(3), 1-13. https://doi.org/10.1080/20004508.2019.1591844

Kigwilu,P\& Githinji,J. (2015). Teacher factors Influencing Effective Implementation of Artisan and Craft Curriculum in Community Colleges in Kenya. American Scientific Research Journal for Engineering, Technology, and Sciences(ASRJETS), 14(2), 129-143.

King Rice, J. (2010). The Impact of Teacher Experience: Examining the Evidence and Policy Implications (CALDER Policy Brief 11). Available online at http://www.caldercenter.org/publications/impact-teacher-experience-examiningevidence-andpolicy-implications

Kinyua,R.J.(2012). Effect of Teacher Related Factors on Implementation of Integrated Kiswahili Curriculum in Public Schools in Nuene Division, Imenti Soyth District, Kenya. [Master's Thesis], University of Nairobi.

Komolafe, M.O. (1989). Teacher Characteristics and Pupil's Achievement in Social Studies in Oyo State Secondary Schools. [Ph.D. Dissertation], University of Ibadan.

Liniet,M.M. (2014). Teacher Related Factors Affecting Implementation of Integrated English Curriculum in Public Secondary School in Ekerenyo Division Nyamira Country ,Kenya .[Master's Thesis], University of Nairobi.

Magoma, C.M. (2011), Curriculum Innovation in Kenya: A case of the Introduction and Implementation of Secondary School Integrated English in Nairobi. [Ph.D. Dissertation], Kenyatta University.

Mutoro, J.M. (2001). Factors Affecting implementation of curriculum for learning impaired. A case study of Webuye schools for the deaf Bungoma, District. [Unpublished M.Ed. Thesis], Kenyatta University.

Nassaji, H. (2015). Qualitative and descriptive research: Data type versus data analysis. Language Teaching Research, 19(2), 129-132. https://doi.org/10.1177/1362168815572747

Nengwekhulu, R.H. (2008). Reflection on Improving Teacher Performance. Africa Educational Review, 5 (2), 338-335. https://doi.org/10.1080/18146620802450041

Ogundare S. F (2001). Purposes and Problems of Recess in Nigerian Primary Schools. UAD Journal of Education 2 (1), 4 - 8.

Ojo,J.K.(2008). Student,Teacher and School- Related Factor Variables as Correlate of Senior Secondary

School Students' Achievement in English Language .[Ph.D. Post Field Defense Paper], University of Ibadan.

Olivia, F.P. (1988). Developing the Curriculum 2ndedition. Georgia Southern college: Harper Collins Publisher.

Ong'ele, A.S. (2007). Effects of Teacher Characteristics on Teaching of Mathematics in Secondary Schools in Kisumu District. [M.ED Thesis], Maseno University.

Owusu,A.A\&Yiboe,K.T.(2013).Teacher Qualifications, Experience and perceptions as Predictors of Implementation of the Shs French Curriculum in China . International Journal of Education and Research, 1(10),1-12.

Papay, J. and Kraft, M. (2014). Productivity Returns to Experience in the Teacher Labor Market: Methodological Challenges and New Evidence on Long-Term Career Improvement. (Brown University). Journal of Public Economic, 130,105-119. http://scholar.harvad.edu/files/mkraft/files/lpubec returns_to_experience_manuscript___r2.pdf 
Rahman ,M.M.(2018). Factors Affecting Teachers' Implementation of Communicative Language Curriculum in Bangladesh. [Master's Thesis], University Sains Malaysia.

Rice, J. (2004). Teacher Quality: Understanding the Effectiveness of Teacher Attributes. Economic Policy Institute BPI Books. http://www.epinet.org/content.cfm/books teacher quality execsum intro

Rice, J.K. (2010). The Impact of Teacher Experience: Examining the Evidence and Policy implications. Urban Institute, 2100 M. street, N.W. Washington D.C, 20037 @2010

Robinson,J.E. (2004). Synthesis of Research on Effects of Class Size. Educational Leadership Journal,47 (7),80-90.

Rockoff, J. (2004). The Impact of Individual Teachers on Students' Achievement: Evidence from Panel Data. American Economic Review, 94(2), 247-252.

Sawhney, S. \& Kaur, M. (2011). Teacher Effectiveness In Relation To Self-Concept of

Elementary School Teachers. Indian Streams Research Journal. 1(3),13-14. https://doi.org/10.17977/jip.v5i3.1039

Seweje, R. O, \& Jegede, S. A. (2005). Science Education and Science Teaching Methods. Lagos: Atilantic Association.

Strauss, R. \& Vogt, W. (2001). Effect of Knowledge and Pedagogy on Student Achievement. A paper presented at the annual of educational finance association, University of California. Aviable online at http://www.newsroom.ucr.edu

Tenai,N.k.(2017). Teacher Factors Influencing Integration of Information Communication Technology in Teaching of English Language in Secondary Schools in Eldoret-East Sub-County, Kenya. [Master's Thesis], Strathmore University.

Thuranira,T.S. (2010). Prespectives on the Teaching Profession in Kenya. [PhD Dissertation], University of Maryland, College Park.

Ummekusum and Khajapeer, M. (1985). Teacher Educators' Effectiveness: A Research Study. Indian Educational Review, 20(2),501-516.

Vicky,C.(2016). Teacher Factors Influencing Implementation of Integrated English Curriculum in Public Secondary Schools in Nandi East Sub County. [Master's Thesis], University of Nairobi.

Wainaina P.N. (1984). Teaching of Christian Religious Education: Problems Facing Teachers in Implementation the New CRE Syllabus. In Primary School of Thika Municipality. [Unpublished M .Ed PTE Thesis], Nairobi University.

Wandera ,S. N .(2019). Influence of Teaching Experience on Pupils' Performance at Kenya Certificate of Primary Examination in English subject in Kenya. IOSR Journal of Research \& Method in Education (IOSR-JRME), 9(3), 24-30. https://doi.org/10.9790/1959-0903032430

Wolters, C. A., \& Daugherty, S. G. (2007). Goals Structures and Teachers' Sense of Efficacy: Their Relation and Association to Teaching Experience and Academic Level. Journal of Educational Psychology, 99 (1), 181-193. https://doi.org/10.1037/0022-0663.99.1.181 